Review

\title{
Monoclonal Antibody Therapies against Anthrax
}

\section{Zhaochun Chen $^{1, *}$, Mahtab Moayeri ${ }^{2}$ and Robert Purcell ${ }^{1}$}

1 Laboratory of Infectious Diseases National Institute of Allergy and Infectious Diseases, National Institutes of Health, Bethesda, MD 20892, USA; E-Mail: rpurcell@ niaid.nih.gov

2

Laboratory of Bacterial Diseases, National Institute of Allergy and Infectious Diseases, National Institutes of Health, Bethesda, MD 20892, USA; E-Mail: mmoayeri@ niaid.nih.gov

* Author to whom correspondence should be addressed; E-Mail: zchen@ niaid.nih.gov;

Tel.: +1-301-594-2308; Fax: +1-301-402-0524.

Received: 10 June 2011; in revised form: 6 August 2011 / Accepted: 10 August 2011 /

Published: 15 August 2011

\begin{abstract}
Anthrax is a highly lethal infectious disease caused by the spore-forming bacterium Bacillus anthracis. It not only causes natural infection in humans but also poses a great threat as an emerging bioterror agent. The lethality of anthrax is primarily attributed to the two major virulence factors: toxins and capsule. An extensive effort has been made to generate therapeutically useful monoclonal antibodies to each of the virulence components: protective antigen (PA), lethal factor (LF) and edema factor (EF), and the capsule of $B$. anthracis. This review summarizes the current status of anti-anthrax mAb development and argues for the potential therapeutic advantage of a cocktail of mAbs that recognize different epitopes or different virulence factors.
\end{abstract}

Keywords: Bacillus anthracis; anti-PA mAbs; anti-LF mAbs; anti-EF mAbs; anti-capsule mAbs; post-exposure treatment of anthrax; a cocktail of mAbs

\section{Anthrax Disease and Its Virulence Determinants}

Bacillus anthracis, the causative agent of anthrax, is a Gram-positive, spore-forming bacterium that infects mostly herbivores. Humans are occasionally infected when exposed to contaminated animal products. However, anthrax poses a great threat as an emerging bioterror agent, highlighted by the anthrax attacks in 2001 [1,2]. 
There are three forms of anthrax disease, cutaneous, gastrointestinal and inhalational anthrax, depending on the route of infection. Inhalational anthrax is the deadliest form and the form used as a biological weapon in 2001. The high lethality of inhalational anthrax is largely attributed to the efficient replication of the bacterium and the action of its toxins. Following inhalation, spores are taken up either by alveolar macrophages or pulmonary dendritic cells and transported to local lymph nodes. These spores then germinate over the course of 2 to 43 days. Clinical symptoms develop rapidly after germination, and coincide with the production of toxins. Actively dividing bacilli produce three toxin components: protective antigen (PA), lethal factor (LF) and edema factor (EF). PA binds to cellular receptors and acts as a vehicle to deliver LF or EF into the cytosol where they exert their enzymatic activities (for review, see van der Goot, G. \& Young, J.A. 2009) [3]. LF is a zinc-dependent protease that cleaves mitogen-activated protein kinase kinases [4,5]. EF is a calcium-calmodulin-dependent adenylate cyclase [6]. The combination of PA with LF results in lethal toxin (LT). LT can replicate symptoms of anthrax disease when injected into animals (for review, see Moayeri, M. \& Leppla, S.H. 2009) [7]. PA combines with EF to form edema toxin (ET) which can produce a range of toxic effects in the host (for review, see Moayeri, M. \& Leppla, S.H. 2009) [7].

In addition to the anthrax toxins (LT and ET), the vegetative bacillus also produces a capsule composed of a polymer of D-glutamic acid linked by $\gamma$-peptidyl bonds ( $\gamma$ DPGA). The toxins and the capsule comprise two major virulence factors that are associated with anthrax pathogenesis. The anthrax toxins play a key role in virulence by suppressing immune cell and cytokine responses, thereby promoting bacterial survival at early stages of infection, while inducing the shock-like death associated with anthrax at later stages following bacterial outgrowth in the blood [8]. On the other hand, the $\gamma$ DPGA capsule allows bacteria to evade phagocytosis and has been shown to be essential for bacterial dissemination in the mouse and primate animal models $[9,10]$. The genes responsible for producing these two virulence factors are carried by two plasmids, pXO1 and pXO2, respectively. The loss of either plasmid results in attenuation of virulence [11,12], confirming the essential role of each factor for full virulence.

\section{The Limitations of Currently Recommended Post-Exposure Treatment}

Current CDC recommendations following potential exposure to aerosolized $B$. anthracis spores are 60 days of oral antibiotics combined with a 3-dose series of the PA-based anthrax vaccine (anthrax vaccine adsorbed, AVA, BioThrax) [13]. While antibiotics and vaccination are an integral part of medical care, both have limitations. Antibiotics are effective in killing bacteria, but they are unable to clear released toxins from the bloodstream. Thus, unless exposure is diagnosed early enough for antibiotic treatment to prevent significant bacterial replication, patients will succumb to toxin-induced disease even after the killing of all bacteria [1]. In addition, there is growing concern about the possibility that a future bioterror attack could involve antibiotic resistant strains. Mutant strains that are resistant to the currently recommended antibiotics doxycycline and ciprofloxacin are rare in nature, but such resistant strains could be readily generated using straightforward experimental procedures in the laboratory $[14,15]$. The need for up to 60 days of antibiotic therapy tends to decrease compliance, as seen in the treatment associated with the 2001 attacks, for which the adherence rate was estimated to be $42 \%[16,17]$. The current PA-based vaccine requires repeated administration and at least 4 weeks 
for development of anti-PA protective titers. Given the short incubation time and rapid disease progression of inhalational anthrax, vaccination is unlikely to afford protection after exposure. Thus, there exists a need for improved therapies to augment available treatment options for inhalational anthrax.

\section{Passive Immunization through Treatment with mAbs}

Passive immunization with protective antibodies represents an attractive option to augment the current post-exposure treatment of anthrax since it can provide immediate and extensive protection that is not dependent on the host response. Indeed, passive immunization with protective antibody has been considered to be the only available countermeasure in biodefense [18]. The overwhelming evidence indicates that antibodies are key players in conferring immunity to anthrax [19-22]. Thus, during the past 10 years, extensive research has been focused on development of therapeutic antibodies to target anthrax. This review summarizes the current status of therapeutic mAbs directed against the major virulence factors: PA, LF, EF and capsule. Furthermore, an argument for the possible therapeutic advantage of a cocktail of several mAbs that recognize different epitopes or different virulence factors (PA, LF, EF and capsule) is presented.

\subsection{Current Status of Anti-Anthrax mAb Development}

\subsubsection{Anti-PA mAbs}

The central role of PA in the pathophysiology of anthrax makes it an excellent therapeutic target. Vaccination with the PA-based human anthrax vaccine [23] or purified PA [24-26] results in the generation of a protective immune response. Passive immunization with polyclonal antibodies against PA is highly protective against challenge with $B$. anthracis spores [27-29]. Moreover, antibody titers against PA correlate with protective immunity against spore challenge [19-22]. The human polyclonal antibodies (anthrax immune globulin, AIG) from plasma of human volunteers who have been vaccinated with AVA have been recommended for use as an Emergency Investigational New Drug. The recent treatment with AIG of a patient who naturally acquired inhalation anthrax showed beneficial effect [30]. However, mAbs are the preferred choice for immunoprophylaxas as they offer several advantages over polyclonal antibodies, including defined specificity, reproducible efficacy, unlimited supply, high purity and increased safety. So far, greater than ten highly potent anti-PA neutralizing mAbs have been generated using different approaches [31-40]. These antibodies neutralize PA by different mechanisms, which include (i) inhibition of receptor binding [35-37,40], (ii) interference with PA heptamer formation [41], (iii) interference with LF or EF binding to PA [31], (iv) blockage of the enzymatic cleavage of PA into PA63 [34], and (v) disruption of preformed PA heptamer through formation of a supercomplex [39,42]. Some of the mAbs are murine-derived and are not useful in clinical applications because they will elicit detrimental anti-antibody immune responses in humans unless "humanized". With the advent of new antibody technologies, it is possible to generate fully human or human-like mAbs. Currently, six such clinically useful anti-PA mAbs are available (Table 1) and each of them will be discussed below. 
Table 1. Human and human-like anti-PA neutralizing monoclonal antibodies.

\begin{tabular}{|c|c|c|c|c|c|}
\hline $\mathbf{m A b}$ & Origin & $\begin{array}{l}\text { Epitope } \\
\text { (Domain) }\end{array}$ & Neutralizing Mechanism & $\begin{array}{l}\text { Animal Model for } \\
\text { in vivo Protection }\end{array}$ & Reference \\
\hline Abthrax & Human & IV & Inhibition of receptor binding & Rat, rabbit and monkey & [37] \\
\hline AVP-21D9 & Human & III & Interference with toxin assembly & Rat $^{1}$ and rabbit ${ }^{2}$ & {$[38,43]$} \\
\hline ETI-204 & Humanized & IV & Inhibition of receptor binding & Rabbit & [40] \\
\hline MDX 1303 & Human & III & $\begin{array}{c}\text { Disruption of preformed PA } \\
\text { heptamer }\end{array}$ & Rabbit and monkey ${ }^{3}$ & [39] \\
\hline IQNPA & Human & IV & Inhibition of receptor binding & Mouse $^{4}$ & [35] \\
\hline W1 & Chimpanzee & IV & Inhibition of receptor binding & Rat and mouse & [36] \\
\hline
\end{tabular}

Abthrax (Raxibacumab) from Human Genome Sciences (HGS) is a fully human mAb derived from a human antibody phage display library licensed by HGS from Cambridge Antibody Technology [37]. The mAb presumably binds to domain IV of PA with an affinity of $2.78 \mathrm{nM}$ and inhibits the binding of PA to its receptor. The in vivo protection was initially demonstrated in a rat toxin-challenge model and pre- and post exposure protection was further demonstrated in both New Zealand white rabbits and cynomolgus monkeys following lethal challenge of B. anthracis Ames spores. AVP-21D9 from Avanir Pharmaceuticals is a fully human $\mathrm{mAb}$ that was generated from human peripheral blood lymphocytes of AVA-immunized donors. The mAb has very high affinity with a $K_{\mathrm{d}}$ of $0.082 \mathrm{nM}$ and inhibits PA heptamer formation $[43,44]$. The protective efficacy was initially demonstrated in a rat toxin-challenge model and pre- and postexposure protection was subsequently confirmed in Dutch-belted dwarf and New Zealand white rabbits following lethal challenge with virulent B. anthracis Ames spores [38]. ETI-204 (Anthim) from Elusys Therapeutics is a humanized, affinity-improved variant of mouse monoclonal antibody, 14B7 [31]. The mAb binds to domain IV of PA with an affinity of $0.33 \mathrm{nM}$ and inhibits PA binding to receptor. Pre- and postexposure protection was demonstrated in New Zealand white rabbits following lethal challenge of B. anthracis Ames spores [40]. MDX1303 (Valortin) from PharmAthene/Medarex is a fully human $\mathrm{mAb}$ that was generated from HuMab transgenic mice that were engineered to express human immunoglobulin [45]. The mAb recognizes domain III of PA and potentially disrupts preformed PA heptamers by formation of a supercomplex in a manner similar to what was described for related antibody 1G3 [42]. The binding affinity has not been reported. Interestingly, the neutralizing activity of the $\mathrm{mAb}$ is dependent on $\mathrm{Fc}$ receptor. Pre-exposure protection was demonstrated in both New Zealand white rabbits and cynomolgus monkeys following lethal challenge with B. anthracis Ames spores [39]. IQNPA from IQ Corporation is a fully human mAb that was developed from peripheral blood lymphocytes from anthrax vaccine-immunized donors using electrofusion hybridoma technology. The mAb recognizes domain IV of PA and presumably inhibits the binding of PA to its cell receptor. Preexposure protection was determined in A/J mice challenged with a lethal dose of unencapsulated toxigenic Sterne strain [35]. W1 from the National Institute of Allergy and Infectious Diseases is a chimpanzee/human chimeric mAb that was recovered from chimpanzees immunized with PA by phage display library technology. W1 has the highest affinity among neutralizing antibodies which interact with the receptor-binding domain IV of PA, with $K_{\mathrm{d}}$ of 
$0.04 \mathrm{nM}$. W1 demonstrated high protective potency in rats using toxin bolus and infusion challenge models as well as in A/J mice challenged with a lethal dose of B. anthracis Sterne spores [36,46].

Currently, HGS has completed safety studies of Abtrhax in humans [47] and was awarded a contract to provide a stockpile of 65,000 doses for treatment of inhalation anthrax. Elusys Therapeutics has completed a Phase 1 clinical study with ETI204 and the drug has received Fast-Track and Orphan Drug status by the FDA. Similarly, a Phase 1 clinical trial with mAb MDX1303 has been completed and the mAb has also received Fast-Track and Orphan Drug status by the FDA. Since different neutralizing mechanisms are used by these mAbs and different animal models, challenge doses, antibody doses, and routes of administration have been used in their testing, it is difficult to directly compare these anti-PA mAbs. Furthermore, limited resources and high costs of testing have delayed the testing of some mAbs in the preferred rabbit or monkey inhalational anthrax models. However, it has been shown that affinity correlates well with neutralizing activity; higher affinity conferred better protection for mAbs that are specific to domain IV of PA $[36,48]$. Since mAbs that are specific to domain IV of PA neutralize by inhibiting the binding of PA to its receptor, it is essential that mAbs bind to PA with higher affinity than the interaction between PA and its receptor. A range of affinities for PA and its receptors has been reported, from 0.17 to $33.3 \mathrm{nM}$ [49-52]. To compete effectively with the PA receptor for PA binding, mAbs need to have an affinity greater than this range. Comparison among four mAbs that neutralize PA by inhibiting the binding of PA to its receptor indicates that the only $\mathrm{mAb}$ that truly falls outside the range of affinities for PA and its receptor is anti-PA W1 (Table 2). However, the efficacy of $\mathrm{W} 1$ relative to other antibodies has not been assessed in the rabbit or non-human primate models.

Table 2. Comparison of human or human-like mAbs that recognize the same receptor-binding domain of PA.

\begin{tabular}{|c|c|c|c|}
\hline $\mathbf{m A b}$ & Affinity $\left(K_{d}\right)$ & Antibody dose for $100 \%$ protection & Reference \\
\hline Abthrax & $2.78 \mathrm{nM}$ & $1.5 \mathrm{mg} / \mathrm{kg}$ in rat ${ }^{2}, 40 \mathrm{mg} / \mathrm{kg}$ in rabbit ${ }^{3}, 40 \mathrm{mg} / \mathrm{kg}$ in monkey ${ }^{4}$ & [37] \\
\hline ETI-204 & $0.33 \mathrm{nM}$ & $4 \mathrm{mg} / \mathrm{kg}$ in rabbit ${ }^{3}$ & [40] \\
\hline IQNPA & $\mathrm{ND}^{1}$ & $7.2 \mathrm{mg} / \mathrm{kg}$ in mouse ${ }^{5}$ & [35] \\
\hline W1 & $0.04 \mathrm{nM}$ & $0.021 \mathrm{mg} / \mathrm{kg}$ in rat ${ }^{2}, 1.6 \mathrm{mg} / \mathrm{kg}$ in mouse ${ }^{6}$ & [36] \\
\hline $\begin{array}{l}{ }^{1} \mathrm{ND} \text { : } \\
\text { inhalat } \\
\text { anthra: } \\
{ }^{5} \mathrm{~A} / \mathrm{J} \\
\mathrm{A} / \mathrm{J} \mathrm{mi} \\
\text { after cl }\end{array}$ & $\begin{array}{l}\text { letermined; } \\
\text { anthrax mo } \\
\text { del challeng } \\
\text { were challe } \\
\text { ere challeng } \\
\text { ige. }\end{array}$ & $\begin{array}{l}\text { Fischer } 344 \text { rats were challenged with LT; }{ }^{3} \text { New Zealand } \\
\text { del with } \text { B. anthracis Ames spores; }{ }^{4} \text { Cynomolgus macaque } \\
\text { d with } B \text {. anthracis Ames spores. } 90 \% \text { protection at the dose } \\
\text { nged with } 24 \mathrm{LD}_{50} \text { of } B \text {. anthracis Sterne spores; }{ }^{6} \text { Unpubl } \\
\text { d with } 2 \times 10^{7} \text { Stern spores }\left(\sim 1000 \mathrm{LD}_{50}\right) \text {. All PBS-treated mic }\end{array}$ & $\begin{array}{l}\text { hite rabbit } \\
\text { halational } \\
\text { indicated; } \\
\text { shed data. } \\
\text { died } 48 \mathrm{~h}\end{array}$ \\
\hline
\end{tabular}




\subsubsection{Anti-LF mAbs}

LF plays a pivotal role in cytotoxicity and progression of disease in the infected host [53]. Currently, several neutralizing mAbs specific to LF have been reported. Some of the well-characterized anti-LF mAbs are listed in Table 3. Most of them are murine-derived and are not suitable for use in humans, and therefore, will not be discussed further. IQNLF is a fully human mAb, while LF10E and LF11H are chimpanzee/human chimeric mAbs. IQNLF recognizes domain I of LF and thus likely inhibits the binding of LF to PA which occurs through this domain. A single dose of $180 \mu \mathrm{g}$ of IQNLF conferred $100 \%$ protection to $\mathrm{A} / \mathrm{J}$ mice that were challenged with $24 \mathrm{LD}_{50}$ of B. anthracis Sterne spores [35]. MAbs LF10E and LF11H bind to domain I of LF with affinities of $0.69 \mathrm{nM}$ and $7.4 \mathrm{nM}$, respectively. Interestingly, neither $\mathrm{mAb}$ inhibits the binding of LF to PA. Initial experiments showed that $\mathrm{LF} 10 \mathrm{E}$ and $\mathrm{LF} 11 \mathrm{H}$ at substoichiometric or equal molar ratios of 1:0.5 and 1:1 of LF to mAb, respectively, conferred $100 \%$ protection of Fischer 344 rats from challenge with LT [54]. A recent experiment showed that $200 \mu \mathrm{g}$ of LF10E provided $100 \%$ protection of $\mathrm{A} / \mathrm{J}$ mice challenged with $1000 \mathrm{LD}_{50}$ of $B$. anthracis Sterne spores (data not shown).

Table 3. Characteristics of available anti-LF neutralizing mAbs.

\begin{tabular}{ccccccc}
\hline mAb & Origin & $\begin{array}{c}\text { Affinity } \\
\left(\boldsymbol{K}_{\mathbf{d}}\right)\end{array}$ & $\begin{array}{c}\text { Epitope } \\
(\text { Domain })\end{array}$ & $\begin{array}{c}\text { In vitro } \text { Neutralization } \\
\left(\mathbf{E C}_{\mathbf{5 0}}\right)\end{array}$ & In vivo Neutralization & Reference \\
\hline LF8 & Mouse & ND $^{1}$ & I & $+(\mathrm{ND})^{3}$ & Athymic nude mouse $^{4}$ & {$[55]$} \\
9A11 & Mouse & $70.1 \mathrm{nM}$ & ND & $1.3 \mathrm{nM}$ & Balb/C mouse $^{5}$ & {$[33]$} \\
$\mathbf{1 0 G 3}$ & Mouse & $20 \mathrm{nM}^{2}$ & I & $+(\mathrm{ND})$ & Fischer 344 rat & {$[56]$} \\
$\mathbf{2 E 7}$ & Mouse & $87 \mathrm{nM}^{2}$ & I & $+(\mathrm{ND})$ & Fischer 344 rat & {$[56]$} \\
3F6 & Mouse & $40 \mathrm{nM}^{2}$ & I & $+(\mathrm{ND})$ & Fischer 344 rat & {$[56]$} \\
$\mathbf{5 B 1 3 B 1}$ & Mouse & $2.62 \mathrm{nM}$ & III & $1.4 \mathrm{nM}$ & Fischer 344 rat & {$[57]$} \\
3C16C3 & Mouse & $8.18 \mathrm{nM}$ & III & $4.2 \mathrm{nM}$ & Fischer 344 rat & {$[57]$} \\
IQNLF & Human & ND & I & $0.1 \mathrm{nM}$ & A/J mouse & {$[35]$} \\
LF10E & Chimpanzee & $0.69 \mathrm{nM}$ & I & $0.1 \mathrm{nM}$ & Fischer 344 rat and A/J & {$[54]$} \\
LF11H & Chimpanzee & $7.4 \mathrm{nM}$ & I & $400 \mathrm{nM}$ & Fischer 344 rat & {$[54]$} \\
\hline
\end{tabular}

${ }^{1}$ ND: not determined; ${ }^{2}$ Calculated IgG concentration for $50 \%$ maximal binding in ELISA based on original data; ${ }^{3}$ Positive in in vitro neutralization assay, but $\mathrm{EC}_{50}$ was not determined; ${ }^{4} \mathrm{MAb}$ and LT were injected intravenously into athymic nude (nu/nu) mice daily; ${ }^{5}$ Balb/C mice were injected with $\mathrm{mAb}$ and then challenged with LT intraperitoneally.

\subsubsection{Anti-EF mAbs}

Fewer neutralizing mAbs to EF have been reported as compared to mAbs against PA and LF (Table 4) [58-60]. This is perhaps because EF has been considered to contribute less to the lethality of anthrax infection [61,62] and epitopes in EF that elicit nonneutralizing mAbs appear to be immunodominant as most mAbs to EF reported thus far do not neutralize EF [58-60]. Nevertheless, one of the EF-neutralizing mAbs, EF13D is very promising for therapeutic use [59]. EF13D is a chimpanzee/human $\mathrm{mAb}$ that can neutralize EF in vitro in the subnanomolar range. The therapeutic usefulness of the antibody was demonstrated by its efficient prevention of local edema formation in a 
murine footpad model, as well as protection of mice from death following edema toxin challenge. EF13D binds to a conformational epitope within domain III of EF with very high affinity ( $K_{\mathrm{d}}$ of 0.05-0.12 nM). The antibody can not only inhibit the binding of calmodulin $(\mathrm{CaM})$ (which is required for activity) to EF, but also can displace pre-bound CaM from the EF-CaM complex.

Table 4. Characteristics of anti-EF neutralizing mAbs.

\begin{tabular}{|c|c|c|c|c|c|}
\hline $\mathbf{m A b}$ & Origin & Affinity $\left(K_{d}\right)^{1}$ & In Vitro Neutralization ${ }^{2}$ & In Vivo Neutralization ${ }^{3}$ & Reference \\
\hline $9 F 5$ & Mouse & $2 \mathrm{nM}$ & Yes & ND & {$[58]$} \\
\hline $1 \mathrm{E6}$ & Mouse & $5 \mathrm{nM}$ & Yes & ND & [58] \\
\hline $7 G 10$ & Mouse & $9 \mathrm{nM}$ & Yes & ND & [58] \\
\hline 9F3 & Mouse & $830 \mathrm{nM}$ & Yes & No & [60] \\
\hline EF13D & Chimpanzee & $0.05-0.12 \mathrm{nM}$ & Yes & Yes & [59] \\
\hline
\end{tabular}

${ }^{1}$ The affinities for mAbs 1E6, 7G10, 9F5 and 9F3 were estimated from binding assay by ELISA and affinity for $\mathrm{mAb} E F 13 \mathrm{D}$ was determined by surface plasmon resonance on Biacore; ${ }^{2}$ The in vitro neutralization activity was measured by the ability of antibody to inhibit cyclase activity of EF; ${ }^{3}$ In vivo neutralization assay was not determined for mAbs 1E6, 7G10 and 9F5 (ND). Prolonged but, ultimately no survival of A/J mice treated with mAb 9F3 was observed following challenge with Sterne spores. MAb EF13D prevented local edema formation and protected mice from death following challenge with ET.

\subsubsection{Anti-Capsule mAbs}

The capsule is poorly immunogenic and acts as a thymus-independent, type 2 antigen [63]. Due to the lack of effective antibody response to the capsule, the antiphagocytic nature of the capsule ensures the unchecked proliferation of bacilli. Clearly, the current PA-based vaccine would not elicit the production of anti-capsule antibodies and therefore, such antibodies are absent from AIG currently stocked for use as an Emergency Investigational New Drug. The inherently weak immunogenicity of the capsule can be significantly enhanced through conjugation to a strong immunogenic protein carrier [64-67] or by administration of $\gamma$ DPGA in combination with a CD40 agonist mAb [68]. By these approaches, several murine and chimpanzee-derived mAbs that promote effective oposonophagocytosis of B. anthracis have been isolated (Table 5) [68-70]. Passive immunization with these specific anti-capsule mAbs conferred significant protection in naïve mice against spores of the Ames strain. In comparison, the chimpanzee-derived anti-capsule mAbs 11D and 4C had an order of magnitude higher binding affinities and conferred better protection than murine mAbs [70]. More importantly, 11D and 4C not only provided pre-exposure protection, but also protection against lethal infection when mAbs were administrated as late as $20 \mathrm{~h}$ after spore challenge. These mAbs could be particularly useful for treatment of infections with antibiotic-resistant strains. 
Table 5. Comparison of some well characterized anti-capsule neutralizing mAbs.

\begin{tabular}{ccccc}
\hline mAb & Origin & Affinity $\left(\boldsymbol{K}_{\mathbf{d}}\right)^{\mathbf{1}}$ & Antibody Dose for 100\% Protection $^{\mathbf{2}}$ & Reference \\
\hline F26G3 & Mouse & $370 \mathrm{nM}$ & $2-4 \mathrm{mg}$ & {$[69]$} \\
F24F & Mouse & $500 \mathrm{nM}$ & $2 \mathrm{mg}$ & {$[69]$} \\
F26G4 & Mouse & $510 \mathrm{nM}$ & $2-4 \mathrm{mg}$ & {$[69]$} \\
4C & Chimpanzee & $36 \mathrm{nM}$ & $0.3 \mathrm{mg}$ & {$[70]$} \\
11D & Chimpanzee & $64 \mathrm{nM}$ & $0.3-1 \mathrm{mg}$ & {$[70]$} \\
\hline
\end{tabular}

${ }^{1}$ The $K_{\mathrm{d}}$ was determined by fluorescence tryptophan perturbation assay; ${ }^{2}$ Murine model of pulmonary anthrax: Balb/c mice were challenged with lethal infection of Ames spores.

\subsection{Maximizing the Efficacy of Antibody Therapy by Targeting Multiple Epitopes}

Even though a single mAb that neutralizes one of the anthrax virulence components (PA, LF, EF and capsule), particularly PA, may be sufficient to confer significant protection, a mixture of more than one mAb against different targets or epitopes could maximize the protective efficacy. Such combinatorial therapy would not only broaden the spectrum of protection but may also synergize protective efficacy. The synergistic effect of multiple mAbs has been well documented in other diseases. A dramatic synergistic effect has been reported for mAbs to botulinum neurotoxin type A (BoNT/A) [71]. A mixture of three anti-BoNT/A mAbs increased protective efficacy by at least 1000-fold when compared with individual mAbs used alone. A similar effect has been observed for anti-tetanus mAbs, where a combination of two mAbs provided complete protection against a lethal tetanus toxin challenge in mice, while single mAbs were not protective [72]. The benefit of $\mathrm{mAb}$ combinations in the neutralization of Rift Valley fever, HIV and dengue viruses has also been reported [73-76].

For anthrax, several anti-PA mAbs that recognize different epitopes and thereby employ different neutralization mechanisms have been generated. Each $\mathrm{mAb}$, regardless of differences in neutralizing mechanism, demonstrated highly potent neutralizing activity [31-40]. However, a point mutation in the neutralization epitope introduced naturally or intentionally can abolish antibody activity as demonstrated by the involvement of a single amino acid as crucial to neutralizing antibody function in the PA-antibody interaction [77]. Obviously, a cocktail of anti-PA mAbs that recognize different epitopes on PA would broaden the spectrum of protection, which would be much more difficult to overcome by escape mutants since multiple point mutations in different epitopes essential to toxin function would be necessary for escape. Furthermore, it is possible that such a combination of different anti-PA mAbs with different specificities would synergize the protective efficacy.

Synergy between anti-PA and anti-LF antibodies has also been investigated. The efficacy of three mouse mAbs recognizing domain 2 and domain 4 of PA and the $N$-terminus of LF, were tested in a mouse Sterne spore-challenge model, in combination and alone [34]. A combination of $1 \mu \mathrm{g}$ of each $\mathrm{mAb}$ resulted in full protection while individual mAbs at doses of $1 \mu \mathrm{g}$ or $10 \mu \mathrm{g}$ conferred $0-25 \%$ protection. Synergy between anti-PA and anti-LF was also observed in a rat LT-challenge model with anti-PA W1 and anti-LF LF11H [54]. These results are consistent with the notion that although PA plays the central role in protective immunity antibodies against LF and EF can also play an important role in protection [78-80]. 
Anthrax is a complex disease involving several steps to establish infection, including spore germination, proliferation of bacilli and toxin production, leading to bacteremia and toxemia. Ideally, mAbs to each of the virulence factors could be used together, so that a comprehensive protection could be achieved by inhibiting multiple steps of infection (Figure 1). The finding that PA is present on the surface of the dormant spore and that antibodies to PA enhance spore phagocytosis and spore killing by macrophages in vitro [81-83] suggests that anti-PA mAbs may interfere with the early stage of infection. Furthermore, it has recently be shown that toxin function against macrophages and neutrophils is essential to avoiding bacterial clearance by these immune cells and establishing infection, confirming an important role for anti-toxin antibodies in early stages [53]. In addition to anti-toxin antibodies interfering with early steps in infection, the actively dividing vegetative bacteria can be killed by anti-capsule mAbs through opsonophagocytosis. High levels of toxin synthesized later in infection and responsible for lethality in this disease can also be neutralized by anti-PA, -LF and -EF mAbs.

Figure 1. Comprehensive protection could be achieved by a combination of anti-PA, anti-LF, anti-EF and anti-PGA mAbs that target major steps of the infection process.

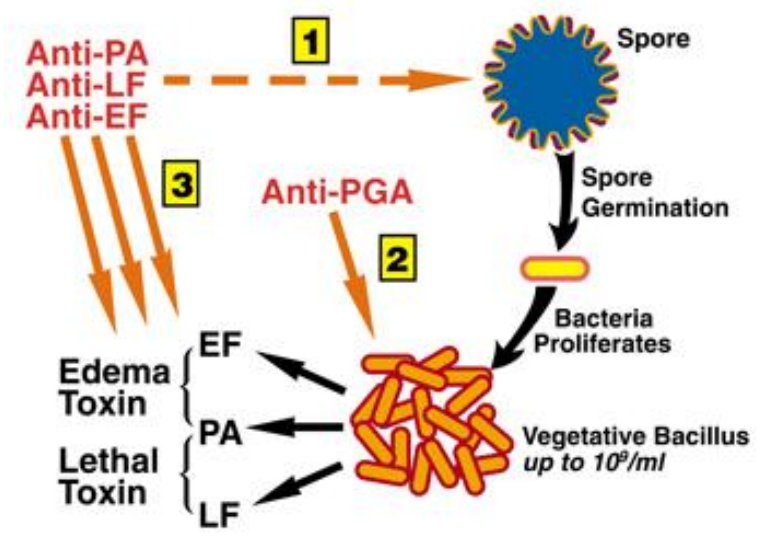

At the very least, the combination of anti-PA and anti-capsule mAbs may be sufficient for maximum efficacy since they combine both anti-bacterial and anti-toxin activities. Even though anti-PA $\mathrm{mAb}$ alone is very effective in protection, a greater therapeutic efficacy has been achieved by passive immunity from anti-PA mAbs in combination with antibiotics [41,84]. Thus, it is reasonable to assume that the same effect could be achieved by combination of anti-PA and anti-capsule mAbs. Actually, anti-capsule mAbs compare favorably with antibiotics in terms of treating antibiotic-resistance strains and providing a prolonged duration of protection. It is critically important that we are prepared to treat anthrax infection that involves antibiotic-resistant strains since such strains could be readily generated in the laboratory as described above. Anti-capsule $\mathrm{mAb}$ is a clear choice for treating such antibiotic-resistance strains. Human IgG1 has a considerably longer serum half-life than antibiotics (21 days vs. 0.1-0.2 day), and this extended duration of efficacy can be quite dramatic. For example, most antibiotics have to be taken once or more daily, but a single dose of an antibody may protect for more than 20 days. The duration of protection is especially important in anthrax treatment because anthrax spores can remain dormant in the lungs for an extended period of time [85-86] and a 60-day course of 
oral antibiotics is recommended, which has resulted in poor compliance [16,17]. By contrast, due to its longer half-life, 2-3 doses of mAbs may be sufficient to provide protection for more than 60 days.

\section{Conclusions}

Several therapeutically useful anti-PA, anti-LF, anti-EF and anti-capsule mAbs have been generated. These mAbs used alone would most likely improve currently recommended post-exposure treatment of anthrax. Use of a cocktail of mAbs that target different epitopes or virulence factors could maximize the protective efficacy as it would not only broaden the spectrum of protection but may also synergize the protective efficacy. In particular, therapy that included an anti-capsule mAb could be useful for treatment of infections with antibiotic-resistant strains.

\section{Conflicts of Interest}

All the authors declare that they have no conflicts of interest.

\section{Acknowledgements}

The research from our laboratories was supported by the Intramural Research Program of the NIH, NIAID.

\section{References}

1. Jernigan, D.B.; Raghunathan, P.L.; Bell, B.P.; Brechner, R.; Bresnitz, E.A.; Butler, J.C.; Cetron, M.; Cohen, M.; Doyle, T.; Fischer, M.; et al. Investigation of bioterrorism-related anthrax, United States, 2001: epidemiologic findings. Emerg. Infect. Dis. 2002, 8, 1019-1028.

2. Inglesby, T.V.; O'Toole, T.; Henderson, D.A.; Bartlett, J.G.; Ascher, M.S.; Eitzen, E.; Friedlander, A.M.; Gerberding, J.; Hauer, J.; Hughes, J.; et al. Anthrax as a biological weapon, 2002: updated recommendations for management. J. Am. Med. Assoc. 2002, 287, 2236-2252.

3. van der Goot, G.; Young, J.A. Receptors of anthrax toxin and cell entry. Mol. Aspects Med. 2009, 30, 406-412.

4. Duesbery, N.S.; Webb, C.P.; Leppla, S.H.; Gordon, V.M.; Klimpel, K.R.; Copeland, T.D.; Ahn, N.G.; Oskarsson, M.K.; Fukasawa, K.; Paull, K.D.; et al. Proteolytic inactivation of MAP-kinase-kinase by anthrax lethal factor. Science 1998, 280, 734-737.

5. Vitale, G.; Bernardi, L.; Napolitani, G.; Mock, M.; Montecucco, C. Susceptibility of mitogen-activated protein kinase kinase family members to proteolysis by anthrax lethal factor. Biochem. J. 2000, 352, 739-745.

6. Leppla, S.H. Anthrax toxin edema factor: a bacterial adenylate cyclase that increases cyclic AMP concentrations of eukaryotic cells. Proc. Natl. Acad. Sci. USA 1982, 79, 3162-3166.

7. Moayeri, M.; Leppla, S.H. Cellular and systemic effects of anthrax lethal toxin and edema toxin. Mol. Aspects Med. 2009, 30, 439-455.

8. Moayeri, M.; Leppla, S.H. The roles of anthrax toxin in pathogenesis. Curr. Opin. Microbiol. 2004, 7, 19-24. 
9. Candela, T.; Fouet, A. Poly-gamma-glutamate in bacteria. Mol. Microbiol. 2006, 60, 1091-1098.

10. Drysdale, M.; Heninger, S.; Hutt, J.; Chen, Y.; Lyons, C.R.; Koehler, T.M. Capsule synthesis by Bacillus anthracis is required for dissemination in murine inhalation anthrax. EMBO J. 2005, 24, 221-227.

11. Ivins, B.E.; Ezzell, J.W., Jr.; Jemski, J.; Hedlund, K.W.; Ristroph, J.D.; Leppla, S.H. Immunization studies with attenuated strains of Bacillus anthracis. Infect. Immun. 1986, 52, 454-458.

12. Spencer, R.C. Bacillus anthracis. J. Clin. Pathol. 2003, 56, 182-187.

13. Stern, E.J.; Uhde, K.B.; Shadomy, S.V.; Messonnier, N. Conference report on public health and clinical guidelines for anthrax. Emerg. Infect. Dis. 2008, 14, e1.

14. Athamna, A.; Athamna, M.; Abu-Rashed, N.; Medlej, B.; Bast, D.J.; Rubinstein, E. Selection of Bacillus anthracis isolates resistant to antibiotics. J. Antimicrob. Chemother. 2004, 54, 424-428.

15. Price, L.B.; Vogler, A.; Pearson, T.; Busch, J.D.; Schupp, J.M.; Keim, P. In vitro selection and characterization of Bacillus anthracis mutants with high-level resistance to ciprofloxacin. Antimicrob. Agents Chemother. 2003, 47, 2362-2365.

16. Williams, J.L.; Noviello, S.S.; Griffith, K.S.; Wurtzel, H.; Hamborsky, J.; Perz, J.F.; Williams, I.T.; Hadler, J.L.; Swerdlow, D.L.; Ridzon, R. Anthrax postexposure prophylaxis in postal workers, Connecticut, 2001. Emerg. Infect. Dis. 2002, 8, 1133-1137.

17. Shepard, C.W.; Soriano-Gabarro, M.; Zell, E.R.; Hayslett, J.; Lukacs, S.; Goldstein, S.; Factor, S.; Jones, J.; Ridzon, R.; Williams, I.; et al. Antimicrobial postexposure prophylaxis for anthrax: adverse events and adherence. Emerg. Infect. Dis. 2002, 8, 1124-1132.

18. Casadevall, A. Passive antibody administration (immediate immunity) as a specific defense against biological weapons. Emerg. Infect. Dis. 2002, 8, 833-841.

19. Clement, K.H.; Rudge, T.L., Jr.; Mayfield, H.J.; Carlton, L.A.; Hester, A.; Niemuth, N.A.; Sabourin, C.L.; Brys, A.M.; Quinn, C.P. Vaccination of rhesus macaques with the anthrax vaccine adsorbed vaccine produces a serum antibody response that effectively neutralizes receptor-bound protective antigen in vitro. Clin. Vaccine Immunol. 2010, 17, 1753-1762.

20. Little, S.F.; Ivins, B.E.; Fellows, P.F.; Pitt, M.L.; Norris, S.L.; Andrews, G.P. Defining a serological correlate of protection in rabbits for a recombinant anthrax vaccine. Vaccine 2004, 22, 422-430.

21. Pitt, M.L.; Little, S.F.; Ivins, B.E.; Fellows, P.; Barth, J.; Hewetson, J.; Gibbs, P.; Dertzbaugh, M.; Friedlander, A.M. In vitro correlate of immunity in a rabbit model of inhalational anthrax. Vaccine 2001, 19, 4768-4773.

22. Reuveny, S.; White, M.D.; Adar, Y.Y.; Kafri, Y.; Altboum, Z.; Gozes, Y.; Kobiler, D.; Shafferman, A.; Velan, B. Search for correlates of protective immunity conferred by anthrax vaccine. Infect. Immun. 2001, 69, 2888-2893.

23. Fellows, P.F.; Linscott, M.K.; Ivins, B.E.; Pitt, M.L.; Rossi, C.A.; Gibbs, P.H.; Friedlander, A.M. Efficacy of a human anthrax vaccine in guinea pigs, rabbits, and rhesus macaques against challenge by Bacillus anthracis isolates of diverse geographical origin. Vaccine 2001, 19, 3241-3247. 
24. Ivins, B.E.; Pitt, M.L.; Fellows, P.F.; Farchaus, J.W.; Benner, G.E.; Waag, D.M.; Little, S.F.; Anderson, G.W., Jr.; Gibbs, P.H.; Friedlander, A.M. Comparative efficacy of experimental anthrax vaccine candidates against inhalation anthrax in rhesus macaques. Vaccine 1998, 16, 1141-1148.

25. Singh, Y.; Ivins, B.E.; Leppla, S.H. Study of immunization against anthrax with the purified recombinant protective antigen of Bacillus anthracis. Infect. Immun. 1998, 66, 3447-3448.

26. Welkos, S.L.; Friedlander, A.M. Comparative safety and efficacy against Bacillus anthracis of protective antigen and live vaccines in mice. Microb. Pathog. 1988, 5, 127-139.

27. Beedham, R.J.; Turnbull, P.C.; Williamson, E.D. Passive transfer of protection against Bacillus anthracis infection in a murine model. Vaccine 2001, 19, 4409-4416.

28. Kobiler, D.; Gozes, Y.; Rosenberg, H.; Marcus, D.; Reuveny, S.; Altboum, Z. Efficiency of protection of guinea pigs against infection with Bacillus anthracis spores by passive immunization. Infect. Immun. 2002, 70, 544-560.

29. Little, S.F.; Ivins, B.E.; Fellows, P.F.; Friedlander, A.M. Passive protection by polyclonal antibodies against Bacillus anthracis infection in guinea pigs. Infect. Immun. 1997, 65, 5171-5175.

30. Walsh, J.J.; Pesik, N.; Quinn, C.P.; Urdaneta, V.; Dykewicz, C.A.; Boyer, A.E.; Guarner, J.; Wilkins, P.; Norville, K.J.; Barr, J.R.; et al. A case of naturally acquired inhalation anthrax: clinical care and analyses of anti-protective antigen immunoglobulin $\mathrm{G}$ and lethal factor. Clin. Infect. Dis. 2007, 44, 968-971.

31. Little, S.F.; Novak, J.M.; Lowe, J.R.; Leppla, S.H.; Singh, Y.; Klimpel, K.R.; Lidgerding, B.C.; Friedlander, A.M. Characterization of lethal factor binding and cell receptor binding domains of protective antigen of Bacillus anthracis using monoclonal antibodies. Microbiology 1996, 142, 707-715.

32. Rosenfeld, R.; Marcus, H.; Ben-Arie, E.; Lachmi, B.E.; Mechaly, A.; Reuveny, S.; Gat, O.; Mazor, O.; Ordentlich, A. Isolation and chimerization of a highly neutralizing antibody conferring passive protection against lethal Bacillus anthracis infection. PLoS One 2009, 4, e6351.

33. Staats, H.F.; Alam, S.M.; Scearce, R.M.; Kirwan, S.M.; Zhang, J.X.; Gwinn, W.M.; Haynes, B.F. In vitro and in vivo characterization of anthrax anti-protective antigen and anti-lethal factor monoclonal antibodies after passive transfer in a mouse lethal toxin challenge model to define correlates of immunity. Infect. Immun. 2007, 75, 5443-5452.

34. Brossier, F.; Levy, M.; Landier, A.; Lafaye, P.; Mock, M. Functional analysis of Bacillus anthracis protective antigen by using neutralizing monoclonal antibodies. Infect. Immun. 2004, 72, 6313-6317.

35. Albrecht, M.T.; Li, H.; Williamson, E.D.; LeButt, C.S.; Flick-Smith, H.C.; Quinn, C.P.; Westra, H.; Galloway, D.; Mateczun, A.; Goldman, S.; et al. Human monoclonal antibodies against anthrax lethal factor and protective antigen act independently to protect against Bacillus anthracis infection and enhance endogenous immunity to anthrax. Infect. Immun. 2007, 75, 5425-5433.

36. Chen, Z.; Moayeri, M.; Zhou, Y.H.; Leppla, S.; Emerson, S.; Sebrell, A.; Yu, F.; Svitel, J.; Schuck, P.; Claire, M., St.; et al. Efficient neutralization of anthrax toxin by chimpanzee monoclonal antibodies against protective antigen. J. Infect. Dis. 2006, 193, 625-633. 
37. Migone, T.S.; Subramanian, G.M.; Zhong, J.; Healey, L.M.; Corey, A.; Devalaraja, M.; Lo, L.; Ullrich, S.; Zimmerman, J.; Chen, A.; et al. Raxibacumab for the treatment of inhalational anthrax. N. Engl. J. Med. 2009, 361, 135-144.

38. Peterson, J.W.; Comer, J.E.; Baze, W.B.; Noffsinger, D.M.; Wenglikowski, A.; Walberg, K.G.; Hardcastle, J.; Pawlik, J.; Bush, K.; Taormina, J.; et al. Human monoclonal antibody AVP-21D9 to protective antigen reduces dissemination of the Bacillus anthracis Ames strain from the lungs in a rabbit model. Infect. Immun. 2007, 75, 3414-3424.

39. Vitale, L.; Blanset, D.; Lowy, I.; O’Neill, T.; Goldstein, J.; Little, S.F.; Andrews, G.P.; Dorough, G.; Taylor, R.K.; Keler, T. Prophylaxis and therapy of inhalational anthrax by a novel monoclonal antibody to protective antigen that mimics vaccine-induced immunity. Infect. Immun. 2006, 74, 5840-5847.

40. Mohamed, N.; Clagett, M.; Li, J.; Jones, S.; Pincus, S.; D’Alia, G.; Nardone, L.; Babin, M.; Spitalny, G.; Casey, L. A high-affinity monoclonal antibody to anthrax protective antigen passively protects rabbits before and after aerosolized Bacillus anthracis spore challenge. Infect. Immun. 2005, 73, 795-802.

41. Peterson, J.W.; Comer, J.E.; Noffsinger, D.M.; Wenglikowski, A.; Walberg, K.G.; Chatuev, B.M.; Chopra, A.K.; Stanberry, L.R.; Kang, A.S.; Scholz, W.W.; et al. Human monoclonal anti-protective antigen antibody completely protects rabbits and is synergistic with ciprofloxacin in protecting mice and guinea pigs against inhalation anthrax. Infect. Immun. 2006, 74, 1016-1024.

42. Radjainia, M.; Hyun, J.K.; Leysath, C.E.; Leppla, S.H.; Mitra, A.K. Anthrax toxin-neutralizing antibody reconfigures the protective antigen heptamer into a supercomplex. Proc. Natl. Acad. Sci. USA 2010, 107, 14070-14074.

43. Sawada-Hirai, R.; Jiang, I.; Wang, F.; Sun, S.M.; Nedellec, R.; Ruther, P.; Alvarez, A.; Millis, D.; Morrow, P.R.; Kang, A.S. Human anti-anthrax protective antigen neutralizing monoclonal antibodies derived from donors vaccinated with anthrax vaccine adsorbed. J. Immun. Based Ther. Vaccines 2004, 2, 5.

44. Wang, F.; Ruther, P.; Jiang, I.; Sawada-Hirai, R.; Sun, S.M.; Nedellec, R.; Morrow, P.R.; Kang, A.S. Human monoclonal antibodies that neutralize anthrax toxin by inhibiting heptamer assembly. Hum. Antibodies 2004, 13, 105-110.

45. Lonberg, N. Human antibodies from transgenic animals. Nat. Biotechnol. 2005, 23, 1117-1125.

46. Altaweel, L.; Chen, Z.; Moayeri, M.; Cui, X.; Li, Y.; Su, J.; Fitz, Y.; Johnson, S.; Leppla, S.H.; Purcell, R.; et al. Delayed treatment with W1-mAb, a chimpanzee-derived monoclonal antibody against protective antigen, reduces mortality from challenges with anthrax edema or lethal toxin in rats and with anthrax spores in mice. Crit. Care Med. 2011, 39, 1439-1447.

47. Subramanian, G.M.; Cronin, P.W.; Poley, G.; Weinstein, A.; Stoughton, S.M.; Zhong, J.; Ou, Y.; Zmuda, J.F.; Osborn, B.L.; Freimuth, W.W. A phase 1 study of PAmAb, a fully human monoclonal antibody against Bacillus anthracis protective antigen, in healthy volunteers. Clin. Infect. Dis. 2005, 41, 12-20.

48. Maynard, J.A.; Maassen, C.B.; Leppla, S.H.; Brasky, K.; Patterson, J.L.; Iverson, B.L.; Georgiou, G. Protection against anthrax toxin by recombinant antibody fragments correlates with antigen affinity. Nat. Biotechnol. 2002, 20, 597-601. 
49. Deshpande, A.; Hammon, R.J.; Sanders, C.K.; Graves, S.W. Quantitative analysis of the effect of cell type and cellular differentiation on protective antigen binding to human target cells. FEBS Lett. 2006, 580, 4172-4175.

50. Wigelsworth, D.J.; Krantz, B.A.; Christensen, K.A.; Lacy, D.B.; Juris, S.J.; Collier, R.J. Binding stoichiometry and kinetics of the interaction of a human anthrax toxin receptor, CMG2, with protective antigen. J. Biol. Chem. 2004, 279, 23349-23356.

51. Liu, S.; Leung, H.J.; Leppla, S.H. Characterization of the interaction between anthrax toxin and its cellular receptors. Cell Microbiol. 2007, 9, 977-987.

52. Singh, Y.; Chaudhary, V.K.; Leppla, S.H. A deleted variant of Bacillus anthracis protective antigen is non-toxic and blocks anthrax toxin action in vivo. J. Biol. Chem. 1989, 264, 19103-19107.

53. Liu, S.; Miller-Randolph, S.; Crown, D.; Moayeri, M.; Sastalla, I.; Okugawa, S.; Leppla, S.H. Anthrax toxin targeting of myeloid cells through the CMG2 receptor is essential for establishment of Bacillus anthracis infections in mice. Cell Host Microbe 2010, 8, 455-462.

54. Chen, Z.; Moayeri, M.; Crown, D.; Emerson, S.; Gorshkova, I.; Schuck, P.; Leppla, S.H.; Purcell, R.H. Novel chimpanzee/human monoclonal antibodies that neutralize anthrax lethal factor, and evidence for possible synergy with anti-protective antigen antibody. Infect. Immun. 2009, 77, 3902-3908.

55. Zhao, P.; Liang, X.; Kalbfleisch, J.; Koo, H.M.; Cao, B. Neutralizing monoclonal antibody against anthrax lethal factor inhibits intoxication in a mouse model. Hum. Antibodies 2003, 12, 129-135.

56. Little, S.F.; Leppla, S.H.; Friedlander, A.M. Production and characterization of monoclonal antibodies against the lethal factor component of Bacillus anthracis lethal toxin. Infect. Immun. 1990, 58, 1606-1613.

57. Lim, N.K.; Kim, J.H.; Oh, M.S.; Lee, S.; Kim, S.Y.; Kim, K.S.; Kang, H.J.; Hong, H.J.; Inn, K.S. An anthrax lethal factor-neutralizing monoclonal antibody protects rats before and after challenge with anthrax toxin. Infect. Immun. 2005, 73, 6547-6551.

58. Little, S.F.; Leppla, S.H.; Burnett, J.W.; Friedlander, A.M. Structure-function analysis of Bacillus anthracis edema factor by using monoclonal antibodies. Biochem. Biophys. Res. Commun. 1994, $199,676-682$.

59. Chen, Z.; Moayeri, M.; Zhao, H.; Crown, D.; Leppla, S.H.; Purcell, R.H. Potent neutralization of anthrax edema toxin by a humanized monoclonal antibody that competes with calmodulin for edema factor binding. Proc. Natl. Acad. Sci. USA 2009, 106, 13487-13492.

60. Winterroth, L.; Rivera, J.; Nakouzi, A.S.; Dadachova, E.; Casadevall, A. Neutralizing monoclonal antibody to edema toxin and its effect on murine anthrax. Infect. Immun. 2010, 78, 2890-2898.

61. Pezard, C.; Berche, P.; Mock, M. Contribution of individual toxin components to virulence of Bacillus anthracis. Infect. Immun. 1991, 59, 3472-3477.

62. Taft, S.C.; Weiss, A.A. Neutralizing activity of vaccine-induced antibodies to two Bacillus anthracis toxin components, lethal factor and edema factor. Clin. Vaccine Immunol. 2008, 15, 71-75.

63. Wang, T.T.; Lucas, A.H. The capsule of Bacillus anthracis behaves as a thymus-independent type 2 antigen. Infect. Immun. 2004, 72, 5460-5463. 
64. Joyce, J.; Cook, J.; Chabot, D.; Hepler, R.; Shoop, W.; Xu, Q.; Stambaugh, T.; Aste-Amezaga, M.; Wang, S.; Indrawati, L.; Bruner, M.; Friedlander, A.; Keller, P.; Caulfield, M. Immunogenicity and protective efficacy of Bacillus anthracis poly-gamma-D-glutamic acid capsule covalently coupled to a protein carrier using a novel triazine-based conjugation strategy. J. Biol. Chem. 2006, 281, 4831-4843.

65. Schneerson, R.; Kubler-Kielb, J.; Liu, T.Y.; Dai, Z.D.; Leppla, S.H.; Yergey, A.; Backlund, P.; Shiloach, J.; Majadly, F.; Robbins, J.B. Poly(gamma-D-glutamic acid) protein conjugates induce IgG antibodies in mice to the capsule of Bacillus anthracis: a potential addition to the anthrax vaccine. Proc. Natl. Acad. Sci. USA 2003, 100, 8945-8950.

66. Rhie, G.E.; Roehrl, M.H.; Mourez, M.; Collier, R.J.; Mekalanos, J.J.; Wang, J.Y. A dually active anthrax vaccine that confers protection against both bacilli and toxins. Proc. Natl. Acad. Sci. USA 2003, 100, 10925-10930.

67. Wang, T.T.; Fellows, P.F.; Leighton, T.J.; Lucas, A.H. Induction of opsonic antibodies to the gamma-D-glutamic acid capsule of Bacillus anthracis by immunization with a synthetic peptide-carrier protein conjugate. FEMS Immunol. Med. Microbiol. 2004, 40, 231-237.

68. Kozel, T.R.; Murphy, W.J.; Brandt, S.; Blazar, B.R.; Lovchik, J.A.; Thorkildson, P.; Percival, A.; Lyons, C.R. mAbs to Bacillus anthracis capsular antigen for immunoprotection in anthrax and detection of antigenemia. Proc. Natl. Acad. Sci. USA 2004, 101, 5042-5047.

69. Kozel, T.R.; Thorkildson, P.; Brandt, S.; Welch, W.H.; Lovchik, J.A.; AuCoin, D.P.; Vilai, J.; Lyons, C.R. Protective and immunochemical activities of monoclonal antibodies reactive with the Bacillus anthracis polypeptide capsule. Infect. Immun. 2007, 75, 152-163.

70. Chen, Z.; Schneerson, R.; Lovchik, J.; Lyons, C.R.; Zhao, H.; Dai, Z.; Kubler-Kielb, J.; Leppla, S.H.; Purcell, R.H. Pre- and postexposure protection against virulent anthrax infection in mice by humanized monoclonal antibodies to Bacillus anthracis capsule. Proc. Natl. Acad. Sci. USA 2011, 108, 739-744.

71. Nowakowski, A.; Wang, C.; Powers, D.B.; Amersdorfer, P.; Smith, T.J.; Montgomery, V.A.; Sheridan, R.; Blake, R.; Smith, L.A.; Marks, J.D. Potent neutralization of botulinum neurotoxin by recombinant oligoclonal antibody. Proc. Natl. Acad. Sci. USA 2002, 99, 11346-11350.

72. Ziegler-Heitbrock, H.W.; Reiter, C.; Trenkmann, J.; Futterer, A.; Riethmuller, G. Protection of mice against tetanus toxin by combination of two human monoclonal antibodies recognizing distinct epitopes on the toxin molecule. Hybridoma 1986, 5, 21-31.

73. Besselaar, T.G.; Blackburn, N.K. The synergistic neutralization of Rift Valley fever virus by monoclonal antibodies to the envelope glycoproteins. Arch. Virol. 1992, 125, 239-250.

74. Li, A.; Baba, T.W.; Sodroski, J.; Zolla-Pazner, S.; Gorny, M.K.; Robinson, J.; Posner, M.R.; Katinger, H.; Barbas, C.F., III; Burton, D.R.; et al. Synergistic neutralization of a chimeric SIV/HIV type 1 virus with combinations of human anti-HIV type 1 envelope monoclonal antibodies or hyperimmune globulins. AIDS Res. Hum. Retrovir. 1997, 13, 647-656.

75. Xu, W.; Smith-Franklin, B.A.; Li, P.L.; Wood, C.; He, J.; Du, Q.; Bhat, G.J.; Kankasa, C.; Katinger, H.; Cavacini, L.A.; et al. Potent neutralization of primary human immunodeficiency virus clade $\mathrm{C}$ isolates with a synergistic combination of human monoclonal antibodies raised against clade B. J. Hum. Virol. 2001, 4, 55-61. 
76. Beltramello, M.; Williams, K.L.; Simmons, C.P.; Macagno, A.; Simonelli, L.; Quyen, N.T.; Sukupolvi-Petty, S.; Navarro-Sanchez, E.; Young, P.R.; de Silva, A.M.; et al. The human immune response to Dengue virus is dominated by highly cross-reactive antibodies endowed with neutralizing and enhancing activity. Cell Host Microbe 2010, 8, 271-283.

77. Rosovitz, M.J.; Schuck, P.; Varughese, M.; Chopra, A.P.; Mehra, V.; Singh, Y.; McGinnis, L.M.; Leppla, S.H. Alanine-scanning mutations in domain 4 of anthrax toxin protective antigen reveal residues important for binding to the cellular receptor and to a neutralizing monoclonal antibody. J. Biol. Chem. 2003, 278, 30936-30944.

78. Price, B.M.; Liner, A.L.; Park, S.; Leppla, S.H.; Mateczun, A.; Galloway, D.R. Protection against anthrax lethal toxin challenge by genetic immunization with a plasmid encoding the lethal factor protein. Infect. Immun. 2001, 69, 4509-4515.

79. Pezard, C.; Weber, M.; Sirard, J.C.; Berche, P.; Mock, M. Protective immunity induced by Bacillus anthracis toxin-deficient strains. Infect. Immun. 1995, 63, 1369-1372.

80. Galloway, D.; Liner, A.; Legutki, J.; Mateczun, A.; Barnewall, R.; Estep, J. Genetic immunization against anthrax. Vaccine 2004, 22, 1604-1608.

81. Welkos, S.; Friedlander, A.; Weeks, S.; Little, S.; Mendelson, I. In-vitro characterisation of the phagocytosis and fate of anthrax spores in macrophages and the effects of anti-PA antibody. J. Med. Microbiol. 2002, 51, 821-831.

82. Welkos, S.; Little, S.; Friedlander, A.; Fritz, D.; Fellows, P. The role of antibodies to Bacillus anthracis and anthrax toxin components in inhibiting the early stages of infection by anthrax spores. Microbiology 2001, 147, 1677-1685.

83. Stepanov, A.V.; Marinin, L.I.; Pomerantsev, A.P.; Staritsin, N.A. Development of novel vaccines against anthrax in man. J. Biotechnol. 1996, 44, 155-160.

84. Karginov, V.A.; Robinson, T.M.; Riemenschneider, J.; Golding, B.; Kennedy, M.; Shiloach, J.; Alibek, K. Treatment of anthrax infection with combination of ciprofloxacin and antibodies to protective antigen of Bacillus anthracis. FEMS Immunol. Med. Microbiol. 2004, 40, 71-74.

85. Friedlander, A.M.; Welkos, S.L.; Pitt, M.L.; Ezzell, J.W.; Worsham, P.L.; Rose, K.J.; Ivins, B.E.; Lowe, J.R.; Howe, G.B.; Mikesell, P.; et al. Postexposure prophylaxis against experimental inhalation anthrax. J. Infect. Dis. 1993, 167, 1239-1243.

86. Meselson, M.; Guillemin, J.; Hugh-Jones, M.; Langmuir, A.; Popova, I.; Shelokov, A.; Yampolskaya, O. The Sverdlovsk anthrax outbreak of 1979. Science 1994, 266, 1202-1208.

(C) 2011 by the authors; licensee MDPI, Basel, Switzerland. This article is an open access article distributed under the terms and conditions of the Creative Commons Attribution license (http://creativecommons.org/licenses/by/3.0/). 